\title{
Dividend Policy in Tunisia: A Signalling Approach
}

\author{
Taleb Lotfi ${ }^{1}$ \\ ${ }^{1}$ ESSECT, Tunis, Tunisia \\ Correspondence: Taleb Lotfi, ESSECT, Tunis, Tunisia. Tel: 216-71-330-266. E-mail: essect@essect.rnu.tn
}

Received: January 20, 2018

Accepted: February 6, 2018

Online Published: February 28, 2018

doi:10.5539/ijef.v10n4p84

URL: https://doi.org/10.5539/ijef.v10n4p84

\begin{abstract}
The main objective of this study was to establish the stock price reaction to dividend announcements of firms quoted at the Tunisian Securities exchange (TSE). To do so, we develop a traditional event study. Two robust results emerge: First, when we observe the 196 announcements of dividends between years 1996-2004, the result is inconsistent with signaling theory, as long as, no abnormal return was observed on the announcement day (event period). Second, When the overall sample is divided into three sub-group (dividend increase, dividend-no-change and dividend), we observe a significant and abnormal return about -1.242 percent and -1.697 percent respectively on day $\mathrm{D}\left(\mathrm{t}_{0}-4\right)$ and $\mathrm{D}\left(\mathrm{t}_{0}+4\right)$ around the dividend announcement day $\left(\mathrm{Dt}_{0}\right)$ only for the sub-group of firms that decreases their dividend. This result corroborates prior research in Tunisian context [Ben Naceur and al. (2006); Guizani and Kouki (2011)] that confirm, by using a different approach, the Lintner's (1956) conclusions which states that Tunisian' firms generally tend to avoid a dividend decrease (or cuts) and can constitute a supporting evidence of the dividend information content hypothesis in TSE.
\end{abstract}

Keywords: dividend announcement, event study, emerging market, signaling theory

\section{Introduction}

Several explanatory theories have been proposed to explain why firms pay dividends but no consensus was until now found. Under the assumption of perfect market Modigliani and Miller (1961), with their best known theory, proved that the dividend policy no matter and then the firm's dividend policy does not affect its value. They show that what really counts is the firm's investment policy as long as investment policy doesn't change. In other words, if we suppose that there's no tax and any other_restrictions, dividend payments would have no impact on the shareholders' value. In other hand, in the real world, change in the dividend policy is often followed by a change in the market value of stocks. The economic argument for investor' preference to dividend income was offered essentially by Graham-Dodd (1951). Subsequently, Walter (1956) and Gordon (1959 and 1962) forwarded the dividend relevancy idea and demonstrate that current stock price would reflect the present value of all expected dividend payments in the future.

Under the assumption of imperfect market, many other theories were also developed, in particular the signaling approach and the information content of dividend. This theory state that dividends are a significant source of information and then can communicate valuable information about present, or may be, future value of the firm.

Under this signaling approach, firms with good news, rather making a simple announcement, can choose to increase their dividend' level. Thus, the announcement of dividend increases (decreases) leads, according to this signaling approach, to an abnormal positive (negative) returns.

In this article we propose to examine the payout policy of the Tunisian firms under the signalling hypothesis and then, to test the reaction to the announcement of a dividend made by firms listed on Tunisian Stock Exchange (TSE). Therefore, we try to investigate whether dividend announcements convey price-sensitive information to investors and to appreciate the views of Tunisian executives and financial analysts (investors) about firms' dividend policies and market signals.

This article is organized as follows: Section 2 develop a review of studies of the dividend policy under signaling approach. Section 3 presents the application of the methodology of event studies to test the impact of the dividend announcement in TSE. Section 4 concludes and remarks.

\section{Dividend Policy under Signalling Hypothesis: A Survey}

Dividend policy is in the hard core of the corporate finance; it has captivated many researchers' interests and 
continues to be an unresolved topic.

Many theories were advanced to explain this "puzzle" (Black (1976)), Easterbrook (1984), Jensen and Meckling (1976) propose that dividends can play an interest role in decreasing agency conflict between the manager and shareholder. Others theories were being advanced and that suppose that dividend can be used as an information vector and then can include an informative content.

In this issue, and based on Lintner's (1956) finding, the dividend signaling model has emerged to explain why firms pay dividends and occasionally adjust their dividend payments. The dividend signaling model suggests that dividend changes provide information content about current and future profitability. Then, due to the information asymmetry between managers and outside investors, managers use the dividend change as a signaling device to convey their expectations about the firm's future profits.

In this context many signaling models were developed, the best known are those of Ross (1977), Bhattacharaya (1979), Miller and Rock (1985), Kalay (1980), Bar-Yosef and Hoffman (1986), John and Williams (1987), Bernheim (1991) and Kumar (1988). All these theories try to explain how firms can use the dividend as a useful signal and then may explain why they prefer to pay out so many dividends.

Empirically, most papers try to test the signaling power of dividend and information content of dividends under several ways in particular the impact of the announcement of dividend either on current or future earnings.

Pettit (1972) showed that a significant price increase (decrease) follows the announcements of dividend increases (decreases). In the same way, Aharony and Swary (1980) found that these price changes hold even after they controlled for contemporaneous earnings announcements.

Charest (1978) studies a variety of methodological concerns related to the techniques of estimating abnormal returns. By using the market model he calculate the average residual (AR) and the cumulative average residual (CAR). The evidence reveals significant abnormal returns in the months following dividend changes.

Grullon, Michaely, and Swaminathan (2002), by using the events studies, found that the average abnormal return to dividend increases was $1.34 \%$ and the average abnormal market reaction to dividend decreases was about $3.71 \%$.

Asquith and Mullins (1983), Healy and Palepu (1988), and Michaely, Thaler and Womack (1995) tested another problematic in particular, they interested in firms which performed dividend initiations and omissions. The results indicated that the market reacts quite severely to those announcements. The average excess return is $3.4 \%$ for initiation and $-7 \%$ for omissions. Michaely, Thaler, and Womack (1995) find that the effect of a unit change in yield had a greater effect on prices for initiations than it did for omissions.

Watts (1973) tested whether earnings of the following year could be explained by the dividend and earning observed in current and past year. The result found, demonstrating that the average dividend coefficients across firms were positive, the average t-statistic was very low. In fact, only the top $10 \%$ of the coefficients were marginally significant.

Benartzi, Michaely, and Thaler (1997), by investigating the relation between dividend changes and future changes in earnings, proved that there's no evidence of a positive relation since all the coefficients were no statistically significant. Moreover, in the two years following the dividend increase, there's no significant correlation between earnings changes and magnitude of the dividend change.

Grullon, Michaely, and Swaminathan (2002), by using the three-factor model of Fama-French, found an abnormal returns of around $8.3 \%$ during the three years following the year of the increase but no abnormal performance for firms who cut their dividends. In the same way Michaely, Thaler and Womack (1995) found an adjusted market return of about $25 \%$ after three years following an introduction and an abnormal return of $15 \%$ for the three years following a failure.

DeAngelo, De Angelo, and Skinner (1996), do not support the hypothesis that an increase in dividends is a signal for future earnings of the firm.

In academic debate it appears then, that the signalling approach does not find a general consensus, in particular, when testing the prediction power of dividend. In fact, many others prior researches (Williams, 1995; Bernheim, 1991; Allen, Bernardo, \& Welch, 2000; Amihud \& Murgia, 1997) found that there's no price' reaction around a change in dividends and then they cannot validate the informational content 'hypothesis.

In Tunisia context, Ben Naceur, Goied and Belanes (2006) tested the Linter's model. The main results found is that dividends are more "sensitive to current earnings than prior dividends " and that the determinants of dividend policy are mainly profits, growth, liquidity of the stock market and the firm's size. Others variables, such as, 
ownership concentration and the financial leverage have no impact on dividend policy. In the same way, Guizani and Kouki (2011) examined the relationship between ownership structure and dividend policy of Tunisian companies. The finding prove a positive relation between dividend policy and stat ownership.

In summary, it appears through the empirical evidence that the information content of dividend is mixed, with some studies support the signaling theory while others contradict it.

\section{The Effect of Annoucement of Dividend on Tunisian Shareholders}

\subsection{Motivations}

There essentially two principal motivations in studying dividend decision in Tunisia. First, a review of the literature showed that the information content of dividends had been comprehensively studied in all developed countries. However, a few numbers of works had been undertaken in emerging markets. Therefore, it was felt that a comprehensive investigation of the impact of dividend announcements on the share prices of Tunisian-listed firms would make a contribution to knowledge. Secondly the present study can give a useful help to identify the determinants of dividend policy in Tunisia and it can helps shed additional light on the inconclusive issues regarding the effects of dividend announcement on stock market and examines the link between current earnings and dividend policy, which is still unexplored in an emerging market like Tunisia.

\subsection{Methodology}

To test the impact of the announcement of the dividend observed in TSE we use the methodology of event studies. This approach was initially used by Ball and Brown (1968) to study the impact of the announcement of annual results of companies with stock prices and was later opted many other authors in useful related areas (Brown \& Warner, 1980; Fama, 1991).

The Event studies, investigate, according to Brown and Warner (1985), the behavior of firms' stock price around corporate or economic events such as dividend announcements and then permits an observer to evaluate the impact of a particular event on a stock price.

To apply this methodology of events studies, we must, at first, define a number of parameters, in particular the event, the event window and the event period.

The event studies supposed to calculate also, an abnormal return (AR), which is the actual return (realized return) minus the normal return (expected return) given the absence of the event. According to the signaling hypothesis, if changes in dividends convey information, the abnormal return (unexpected return) on the event date (dividend announcement) should be significantly different from zero.

Then for firm $i$ and an event observed in date $t$, the abnormal return (unexpected return) can be given as follow:

$$
A R_{i t}=R_{i t}-E\left(R_{i t}\right)
$$

Where $R_{i t}$ is the daily return of the firm $i$ on day $t$. This daily return can be calculated using either a discrete or logarithmic approach. We choose use in this paper the second method supposed more likely to be normally distributed and so conform to the assumptions of standard statistical techniques.

Therefore, logarithmic share returns are calculated as:

$$
R_{i t}=\operatorname{Ln}\left(\frac{\left(P_{i t}-P_{i t-1}-D_{i t}\right)}{P_{i t-1}}\right)
$$

where $R_{i t}$ is the daily return of firm $i$ on day $t ; L n$ is the natural $\log ; P_{i t}$ represents the share price of firm $i$ on day $\mathrm{t} ; P_{i t-1}$ is the share price of firm $i$ on the previous day and $D_{i t}$ is the dividend for firm $i$ payed on day $t$.

The expected return $E\left(R_{i t}\right)$ can be computed using various methods. Similar to Brown and Warner (1980), we use in this paper two different methods: the first method supposed to calculate the Mean Adjusted Abnormal Returns (MEAR) while in second method we compute the Market Adjusted Abnormal Return (MAAR)). These measures used for estimation daily share returns (Brown \& warner, 1985).

Using the first method (MEAR) abnormal return can be calculated as follow:

$$
R A_{i t}=R_{i}-K_{i}
$$

Where $K_{i}$ is the average stock' returns calculated over the estimation period using the following formula:

$$
K_{i}=\frac{1}{1+T} \sum_{\mathrm{t}=\mathrm{t}_{0}}^{\mathrm{t}=\mathrm{t}_{\mathrm{n}}} \mathrm{R}_{\mathrm{it}}
$$

In the second method (MAAR), the abnormal returns were estimated as the difference between the actual return earned by share on a particular day and the return on the market, approximated by the market index, for the same 
day. The abnormal return can be calculated as follows:

$$
R A_{i t}=R_{i t}-R M_{t}
$$

Where $R M_{t}$ is the market index observed on date $t$

MEAR or MAAR, are all calculated over an event period, starting with day $\mathrm{D}\left(t_{0}-25\right)$ and finish on day $\mathrm{D}\left(t_{0}+25\right)$ with $\mathrm{D}\left(\mathrm{t}_{0}\right)$ supposed to be the dividend announcement day. Unexpected returns $\left(\mathrm{AR}_{\mathrm{it}}\right)$ were calculated over the event window, 11-day period, from $D\left(t_{0}-5\right)$ to $D\left(t_{0}+5\right)$ centered on the dividend announcement date.

According to the null hypothesis, $\left(\mathrm{H}_{0}\right)$, the abnormal (excess) returns observed on the announcement date $\mathrm{D}\left(\mathrm{t}_{0}\right)$ should not be significantly different from zero. By contrast, and according to the information content' hypothesis, the dividend increasing firms shall earn positive abnormal (excess) returns, dividend decreasing' firms achieve negative abnormal (excess) returns while dividend-no-change' companies only earn normal returns around event widow (the 11-day).

Afterwards we calculate the Cumulative Abnormal Returns (CAR) above the event' window, i.e., the_period starting from $\mathrm{D}\left(\mathrm{t}_{0}-5\right)$ to $\mathrm{D}\left(\mathrm{t}_{0}+5\right)$, using this formula:

$$
\begin{aligned}
& C A R_{i t}=\sum_{t=1}^{j} M E A R \\
& C A R_{i t}=\sum_{t=1}^{j} M A A R
\end{aligned}
$$

Where, $C A R_{i t}$ is the cumulative abnormal return for firm i calculated on date $\mathrm{t}, \mathrm{j}$ denotes the day $\mathrm{D}\left(\mathrm{t}_{0^{-}}-5\right)$ to $\mathrm{D}$ $\left(\mathrm{t}_{0}+5\right)$.

Finally, we used a parametric test [Brown and Warner (1980)] to determine the statistical significance either for $M A A R$ or MEAR. The t-statistic calculated the standard deviation of abnormal returns (AR) and Cumulative Abnormal Returns (CAR) of the portfolio of 196 dividend-paying stocks observed on period 1996-2004.

\subsection{Samples Description}

The sample includes 39 companies listed on the Tunisian Stock Exchange (TSE) who announced dividends between years 1996-2004. The total announcement of dividend (numbers of events) is about 196.

For comparison purposes, the dividend announcements, according to the variation of dividend observed between year $t$ and year $t-1$, were divided into three categories. Then we have considered three sub-groups: (sub-group 1) with firms that increase $(D I)$ their dividend level between year $\mathrm{t}$ and year $\mathrm{t}-1$ (64 observations), (sub-group 2) includes firms that decide do not change $(\mathrm{DnC})$ their dividend ratio between year $\mathrm{t}$ and year $\mathrm{t}-1$ ( 83 observations) and finally (sub-group3) includes firms that decrease (or cut) $(D D)$ their dividend between year $\mathrm{t}$ and $\mathrm{t}-1$ (49 observations). The change in dividend per share (DPS) was also being measured as the absolute difference between the dividends paid for one year to the next.

\subsection{Empirical Findings and Analyses}

\subsubsection{Full Sample Results}

Considering in $_{2}$ first $_{2}$ the overall sample with 196 observations and when we observe the firm's reaction around the announcement day and by using the MEAR (MAAR), the findings show that on the announcement dividend day $\left(\mathrm{Dt}_{0}\right)$, an abnormal return with 1.4 percent (1.42 percent ) value is detected but without being statistically significant (t-statistic1.36) (Table 1).

This absence of reaction in Tunisian context, may be due to the fact that the information about dividend payment, made by most Tunisian' firms listed on TSE, often leaks out to the market a few days before the official announcement. Hence, the dividend announcement, on the presumed announcement day, normally carries' no surprise to the market. Overall, and when considering the total number of events (196), the results suggest that the effect of dividend announcement is not strong in TSE and then, the signaling hypothesis can't be validated. 
Table 1. Mean adjusted abnormal return (MEAR) of 39 dividend-paying TSE stocks over a window period starting from day -5 to day +5 relative to dividend announcement day (0-day) and associated Cumulative Abnormal Return (CAR) over the event window (11-day).

\begin{tabular}{cllll}
\hline Day relative to dividend announcement & Average MEAR & t-statistic & CAR & t-statistic \\
\hline-5 & 0,89750769 & 0,86522165 & 0,89750769 & 0,22747385 \\
-4 & 0,81352916 & 0,78426408 & 1,71103685 & 0,43366329 \\
-3 & 0,86877472 & 0,8375223 & 2,57981157 & 0,65385475 \\
-2 & 0,63303879 & 0,61026649 & 3,21285036 & 0,8142988 \\
-1 & 0,90135237 & 0,86892803 & 4,11420273 & 1,04274708 \\
0 & 1,4139213 & $\mathbf{1 , 3 6 3 0 5 8 3 2}$ & 5,52812403 & 1,40110626 \\
1 & 1,56072229 & 1,50457844 & 7,08884632 & 1,79667224 \\
2 & 1,04679029 & 1,00913411 & 8,13563662 & $\mathbf{2 , 0 6 1 9 8 1 8 5} * *$ \\
3 & 1,76072666 & 1,69738805 & 9,89636328 & $\mathbf{2 , 5 0 8 2 3 9 0 5} * *$ \\
4 & 1,39542577 & 1,34522813 & 11,291789 & $\mathbf{2 , 8 6 1 9 1 0 5 2} * *$ \\
5 & 0,9621902 & 0,92757734 & 12,2539792 & $\mathbf{3 , 1 0 5 7 7 8 1 9} * * *$ \\
\hline
\end{tabular}

Note. Asterisks in the last column denotes that the corresponding MEAR is statistically significant. The asterisks $* * * * *$ indicate the level of significance (based on the $t$ values) at respectively 1 and 5 percent level.

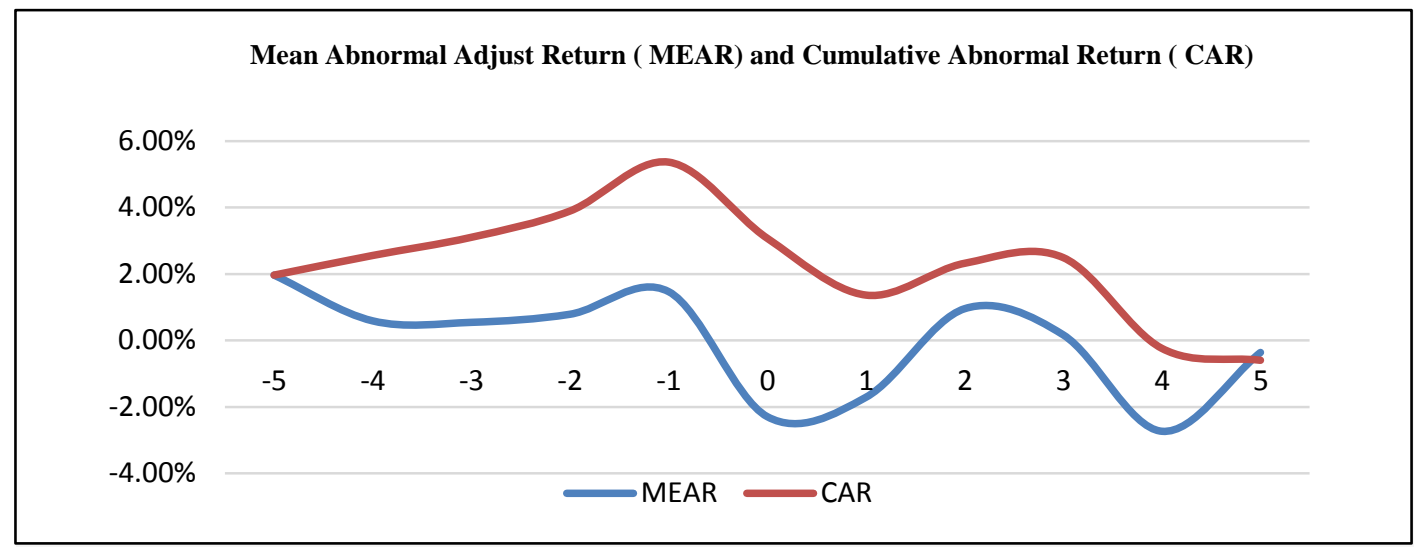

Figure 1. Mean adjusted abnormal return $(M E A R)$ of 39 dividend-paying TSE stocks over a window period starting from day -5 to day +5 relative to dividend announcement day ( 0 -day) and associated Cumulative

Abnormal Return (CAR) over the event period

Table 2. Market adjusted abnormal return $(M A A R)$ of 39 dividend-paying TSE stocks over a window period starting from day -5 to day +5 relative to dividend announcement day (0-day) and associated Cumulative Abnormal Return (CAR) over the event window. (11-day)

\begin{tabular}{ccccc}
\hline Day relative to dividend announcement & MAAR & t-statistic & CAR & t-statistic \\
\hline-5 & 0,90197958 & 0,86848822 & 0,90197958 & 0,2278707 \\
-4 & 0,8164923 & 0,78617516 & 1,71847188 & 0,43414441 \\
-3 & 0,87111368 & 0,83876839 & 2,58958555 & 0,65421733 \\
-2 & 0,64183277 & 0,61800091 & 3,23141833 & 0,8163661 \\
-1 & 0,90327065 & 0,86973135 & 4,13468898 & 1,04456297 \\
0 & 1,42042909 & $\mathbf{1 , 3 6 7 6 8 7 2 1}$ & 5,55511807 & 1,40341164 \\
1 & 1,5616394 & 1,50365424 & 7,11675747 & 1,79793483 \\
2 & 1,04748494 & 1,00859082 & 8,1642424 & $\mathbf{2 , 0 6 2 5 6 5 1 2} * *$ \\
3 & 1,76237934 & 1,69694051 & 9,92662174 & $\mathbf{2 , 5 0 7 8 0 2 0 5 * *}$ \\
4 & 1,40665953 & 1,35442892 & 11,3332813 & $\mathbf{2 , 8 6 3 1 7 2 0 6} * *$ \\
5 & 0,96583691 & 0,92997447 & 12,2991182 & $\mathbf{3 , 1 0 7 1 7 5 2 9 * *}$ \\
\hline
\end{tabular}

Note. Asterisks in the last column denotes that the corresponding MAAR (or CAR) is statistically significant. The asterisks ***,** indicate the level of significance (based on the $t$ value) at respectively the 1 and 5 percent. 


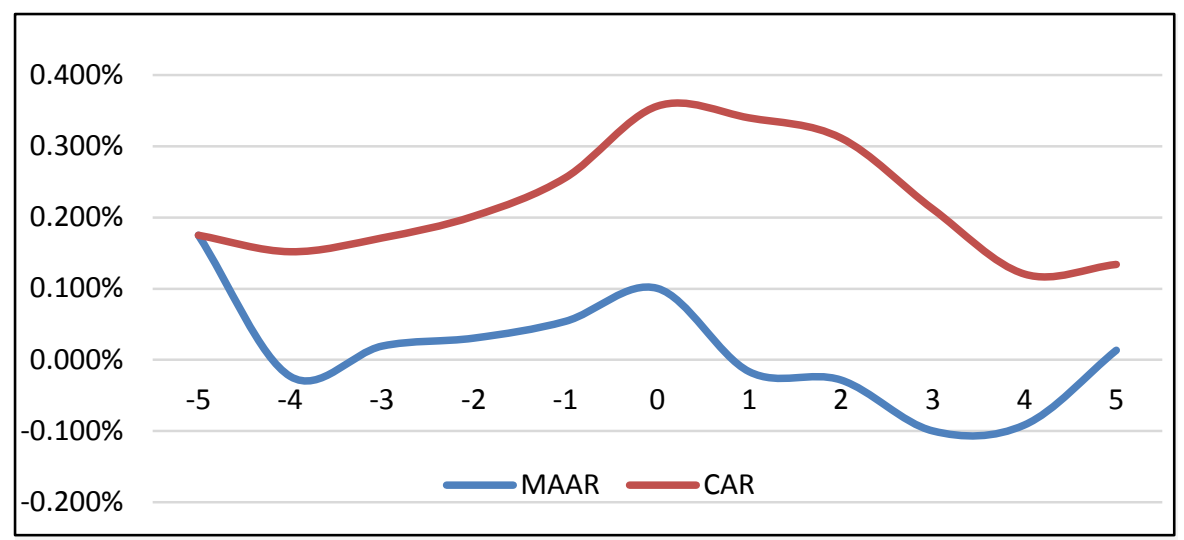

Figure 2. Market adjusted abnormal return $(M A A R)$ of 39 dividend-paying TSE stocks over a window period starting from day -5 to day +5 relative to dividend announcement day (0-day) and associated Cumulative Abnormal Return (CAR) over the event window (11-day)

\subsubsection{Dividends Increases}

In other hands, we are trying to test the market reaction regarding to the change observed in dividend in the current year with past year. The dividend signalling hypothesis argues, as supposed in the literature, that the impact on share price will differ according to the nature of the announcement a dividend increase (decrease) will be associated with positive (negative ) unexpected returns while only normal returns are anticipated when no dividend change is announced.

Considering now the three sub-group and, according the change observed in the dividend level between year $\mathrm{t}$ and $\mathrm{t}-1$, the following results for each sub-group is being observed:

Table 3, reports the abnormal and excess returns for the case of dividend increase announcements (DI) around the 11-day event period, which is interpreted, according to the theory of signal, as a positive signal sent to the market and allowing then information about an improvement in the firm' future performance. The results found do not validate this information content hypothesis, as long as no statistically significant and positive reaction was observed with any of the two used methods (MEAR, MAAR). This result, witch not consistent with the hypothesis of information content of dividends, may be explained by the fact that the decision to increase the level of dividend in TSE was already and fully anticipated by the market. The only mean abnormal adjusted return $(M E A R)$, is observed on the day $\mathrm{D}\left(\mathrm{t}_{0}+1\right)$, the value is -0.14 percent without being statistically significant. This abnormal return can be explained by the attitude of minority of investors, assumed to be uninformed, who had anticipated the increase and then try to revise their anticipations.

Table 3. Mean adjusted abnormal return (MEAR) of 39 dividend-paying TSE stocks over a window period starting from day -25 to day +25 relative to dividend announcement day (0-day) for firms that increase their dividend level between year $\mathrm{t}$ and year $\mathrm{t}-1$ and associated Cumulative Abnormal Return (CAR) over the event period and subsequent days

\begin{tabular}{ccccc}
\hline Day relative to dividend announcement & MEAR & t-statistic & CAR & t-statistic \\
\hline-5 & 0,001751 & 1,20344556 & 0,0140263 & 0.05154230 \\
-4 & 0,000231 & $-0,15885841$ & 0,01379517 & 0.05069296 \\
-3 & 0,000194 & 0,13304785 & 0,01398875 & 0.05140430 \\
-2 & 0,000305 & 0,20994356 & 0,01429421 & 0.05252676 \\
-1 & 0,000542 & 0,37255114 & 0,01483625 & 0.0545186 \\
0 & 0,001005 & 0,69065589 & 0,01584113 & 0.05821121 \\
1 & $-0,000165$ & $-0,1134938$ & 0,0156760 & 0.05760442 \\
2 & $-0,000282$ & $-0,19406621$ & 0,01539364 & 0.05656684 \\
3 & $-0,000998$ & $-0,68586177$ & 0,01439574 & 0.05289987 \\
4 & $-0,000914$ & $-0,62852243$ & 0,01348127 & 0.04953947 \\
5 & 0,000135 & 0,09297168 & 0,01361654 & 0.05003654 \\
\hline
\end{tabular}

Note. Asterisks in the last column denotes that the corresponding MEAR is statistically significant. The asterisks ***, ** indicate the level of significance (based on the $t$ values) at respectively the 1, 5 percent. 


\subsubsection{Constant Dividends}

Table 4, illustrates the unexpected share price returns for the firms (abnormal return) that not change their dividend level $(D n C)$ over the same 11-day period. According to the information content hypothesis and the signaling theory, only normal returns are expected on the announcement day as no new information is thought to have been divulged to the market. In line with the expectations of the signalling argument, the results show insignificant abnormal and excess returns being earned on the announcement date and during all the event window. Specifically, the findings indicate that, on the announcement day $\left(\mathrm{Dt}_{0}\right)$ and using the MAAR method, the observed excess returns was $0.4 \%$ without being statically significant. This result implies that the share' price is fully anticipated by the market and confirm then the finding of most priors researches in Tunisian context (Ben Naceur et al., 2006) that show that the Tunisian companies, mostly prefer to maintain, and then, to not change their payout ratio frequently.

Table 4. Mean adjusted abnormal return (MEAR) of 39 dividend-paying TSE stocks over a window' period starting from day -5 to day +5 relative to dividend' announcement day (0-day) for firms that not change their dividend level ( DnC' Group) between year $\mathrm{t}$ and year $\mathrm{t}-1$ and associated Cumulative Abnormal Return (CAR) over the same period

\begin{tabular}{ccccc}
\hline Day relative to dividend announcement & MEAR & t-statistic & CAR & t-statistic \\
\hline-5 & 0,000608 & 0,680441982 & 0,000607722 & 0,001751 \\
-4 & 0,000213 & 0,238486837 & 0,000820722 & 0,001520 \\
-3 & 0,000649 & 0,727074185 & 0,001470093 & 0,001713 \\
-2 & 0,000158 & 0,177461224 & 0,001628589 & 0,002019 \\
-1 & 0,000381 & 0,426294062 & 0,002009324 & 0,002561 \\
0 & $-0,001405$ & $-1,572893352$ & 0,000604528 & 0,003566 \\
1 & $-0,001043$ & $-1,167424937$ & $-0,000438133$ & 0,003401 \\
2 & 0,000876 & 0,981347257 & 0,000438336 & 0,003118 \\
3 & $-0,001352$ & $-1,513553767$ & $-0,000913462$ & 0,002120 \\
4 & $-0,000508$ & $-0,568918177$ & $-0,00142158$ & 0,001206 \\
5 & 0,001165 & 1,304661903 & $-0,000256348$ & 0,001341 \\
\hline
\end{tabular}

Note. Asterisks in the last column denotes that the corresponding MEAR is statistically significant. The asterisks $* * *, * *$ indicate the level of significance (based on the $t$ values) at respectively the 1, 5 percent level.

\subsubsection{Dividends Decreases}

Considering the firms that decrease their dividend level between current year and past year over the 11-day event period ( $D D$ sub-group). The signalling literature suggests, given the assumption of information asymmetry, that a decrease in the dividend can give a pessimistic news (bad news) to the market, which lead normally to a negative reaction and then a decrease in share prices. Therefore an abnormal and excess return for firms who decide to reduce (or cut) their dividend should be negative and less than zero on the announcement date (or over the event window).

Consistent with the findings from Table 5 there's, and as predictive by the signalling theory, some evidence of significantly and negative excess returns observed on day $\mathrm{D}\left(\mathrm{t}_{0}-4\right)$ and day $\mathrm{D}\left(\mathrm{t}_{0}+4\right)$. In fact the abnormal return on day $\mathrm{D}\left(\mathrm{t}_{0}-4\right)$ was $-1,242 \%$ ( $\mathrm{t}$-statistic -3.44 ) while, the one observed on day $\mathrm{D}\left(\mathrm{t}_{0}+4\right)$ is about $-1.697 \%$ (t-statistic -3.44$)$. The CAR also, is clearly negative and statistically significant from the fourth day after the announcement event and all subsequent days excess.

This result, which is consistent with the signaling hypothesis, suggest that they're mainly two categories of investors in Tunisian context: The first, with investors who are sluggish in reacting to the news of a dividend decrease (or cut) and take time to impound the information into share returns. The second with investors that can anticipate (or being informed) the event and then, react before the official announcement (Table 5).

This finding, in the case of dividend decrease, which is similar to with Grullon, Michaely, and Swaminathan's (2002) results, can constitute a support of dividend information content' hypothesis in the context of Tunisian market. 
Table 5. Mean adjusted abnormal return (MEAR) of 39 dividend-paying TSE stocks over a window period starting from day -5 to day 5 between the dividend announcement day (0-day) for firms that decrease their dividend level between year t and year t-1 ( DD group) and associated Cumulative Abnormal Return (CAR) for the same period.

\begin{tabular}{ccccc}
\hline Day relative to dividend announcement & MEAR & t-statistic & CAR & t-statistic \\
\hline-5 & $1,058 \%$ & 0,14437403 & 0,01057708 & 0,34417319 \\
-4 & $-1,242 \%$ & $-2,51845094 * * *$ & $-0,00184513$ & $-0,06003955$ \\
-3 & $0,339 \%$ & 0,68803158 & 0,00154857 & 0,05038989 \\
-2 & $-0,362 \%$ & $-0,73387591$ & $-0,00207125$ & $-0,06739759$ \\
-1 & $-0,619 \%$ & $-1,25563092$ & $-0,00826463$ & $-0,26892702$ \\
0 & $-0,503 \%$ & $-1,02021118$ & $-0,0132968$ & $-0,43267147$ \\
1 & $-0,009 \%$ & $-0,01908946$ & $-0,01339095$ & $-0,43573534$ \\
2 & $-0,649 \%$ & $-1,31640344$ & $-0,01988409$ & $-0,6470188$ \\
3 & $0,058 \%$ & 0,11731335 & $-0,01930544$ & $-0,62818994$ \\
4 & $-1,697 \%$ & $-3,44142209 * * *$ & $-0,03628018$ & $-1,18054005 * *$ \\
5 & $-0,443 \%$ & $-0,89795422$ & $-0,04070932$ & $-1,32466218 * *$ \\
\hline
\end{tabular}

Note. Asterisks in the last column denotes that the corresponding MEAR is statistically significant. The asterisks $* * *, * *$ indicate the level of significance (based on the $t$ values) at respectively the 1, 5 percent level.

The results presented so far in this paper (Figure 3), indicate that, when we considered the 196 announcements observed between the years 1996-2004, all the observed excess returns earned on the dividend announcement date are not significantly different from zero. But when the overall sample is subdivided into three different groups (DI, DnC and DD), according to changes in dividend observed between year $t$ and $t-1$, we find that the signaling hypothesis is inconsistent for the two sub-groups (DI) and (DnC) however, a significant and negative unexpected return is observed, for the sub-group of firms that decrease (or cut) their dividend on current year (DD), as signalling theory might suggest.

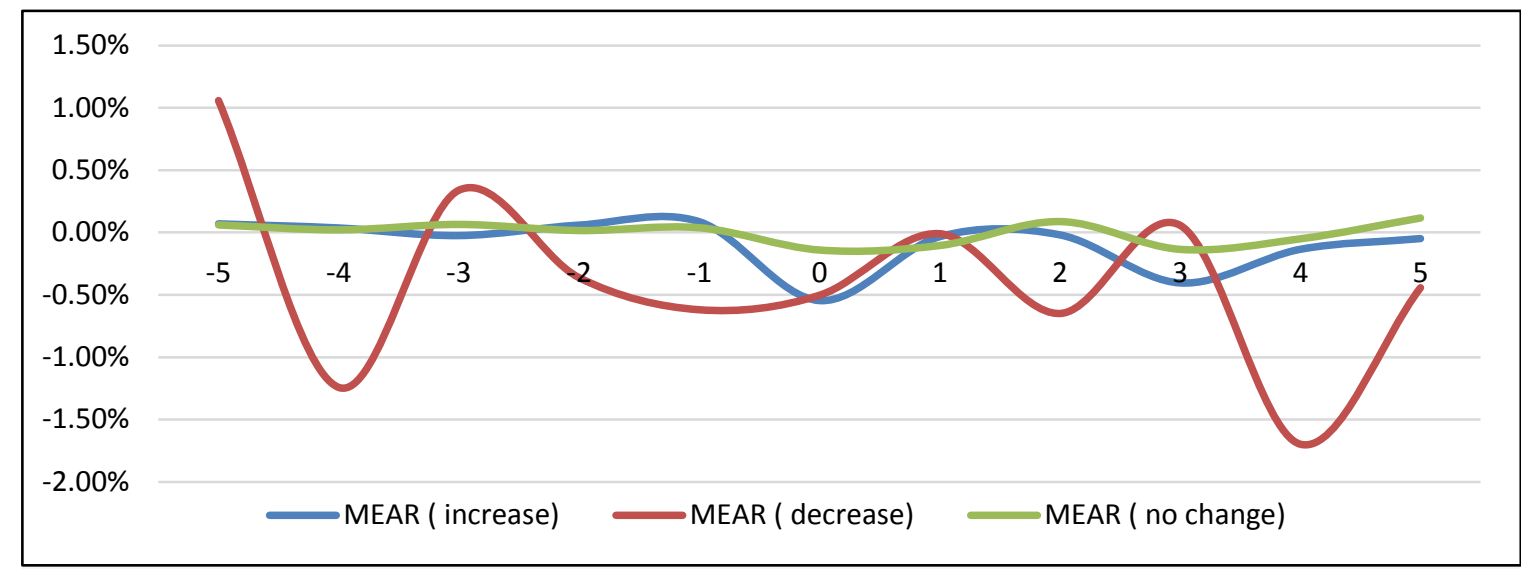

Figure 3. Mean adjusted abnormal return (MEAR) and associated Cumulative Return (CAR) of 39 dividend-paying TSE stocks over a window period starting from day -5 to day +5 relative to dividend announcement day (0-day) regarding the observed evolution of dividend level between year $t$ and $t-1)$ [(DI);

$(\mathrm{DnC})$ or $(\mathrm{DD})]$

\section{Concluding Remarks}

In academic literature, it was suggested that dividend payments have no impact on the shareholders' value in the absence of taxes and other market imperfections (Miller \& Modigliani, 1961). However, other researchers showed that valuation of stock depends essentially on the expected future dividends (Walter, 1956; Gordon, 1959, 1962).

Trying to explain why firms distribute their cash, others theories were also proposed, in particular, the signalling theory and the hypothesis of dividend information' content. This theory, argued that dividend can be used as a 
useful signal and can inform investors about their future earnings and then, about the firm's prospects. In this sense, any change in dividend level (increase or decrease) may be associated to change in profitability and can affect the market firm's value.

The present paper investigates the speed of adjustment of stock prices to dividend announcements. The analysis was conducted by calculating abnormal returns (AR) and Cumulative Abnormal Return (CAR) over the event window of 11 days. Also we examined the impact of positive (negative) dividend changes on stock prices in order to investigate if the dividend signalling hypothesis holds in the Tunisian stock market.

We used to test the signalling hypothesis and then to ascertain the impact of dividend announcements on the share prices of firms listed on the TSE, a conventional event study' methodology. A total number of 196 events (dividend announcements) were investigated over the period 1996-2004.

The main findings prove that, a negative and abnormal return is observed only for sub-group of firms that decreases (or cut) their dividend level between current year and past year (sub-group (DD). In this case only, an abnormal (excess) return is observed on day $\mathrm{D}(\mathrm{t}-4)$ and day $\mathrm{D}(\mathrm{t}+4)$ with respectively $(-1.242)$ and (-1.697). The CAR is also negative in the same case with $-3.6 \%$ (4\%) in fourth (fifth) day after the dividend announcement.

All these result allow as to conclude that that the dividend decrease (cuts) was generally seen as bad news and the reduction in payouts leads to a decrease in share prices in TSE.

This result corroborates prior research in Tunisian context (Ben naceur et al., 2006; Guizani \& Kouki, 2011) that confirm the Lintner's (1956) conclusions, which states that firms generally tend to avoid a dividend decrease (or cuts) and set a long-term target dividend payout ratio and slowly adjust it in response to earnings changes and then, tend to increase dividend payments only when managers believe that future cash flows would be sufficient to support more dividend payments in current and subsequent years. Thus, it appears that a dividend decrease (cuts) in Tunisian context was generally seen as bad news and the reduction in payouts leads to a decrease in share prices.

\section{References}

Aharony, J., \& Swary, I. (1980). Quarterly Dividend and Earning Announcements and Stockholder's Returns. The Journal of Finance, 35, 1-12. https://doi.org/10.1111/j.1540-6261.1980.tb03466.x

Akerlof, G. (1970). The market for Lemon: Quality uncertainty and the market Mechanism. Quarterly Journal of Economics, 89, 488-500. https://doi.org/10.2307/1879431

Allen, F., \& Michaely, R. (2001). Payout Policy. Wharton school Working Paper. https://doi.org/10.2139/ssrn.309589

Allen, F., Bernardo, A., \& Welch, I. (2000). A theory of dividend based on tax clientele. The Journal of Finance, 55(6), 2499-2536. https://doi.org/10.1111/0022-1082.00298

Ambarish, R., John, K., \& Williams, J. (1987). Efficient signalling with dividends and investments. The Journal of Finance, 42, 321-343. https://doi.org/10.1111/j.1540-6261.1987.tb02570.x

Amihud, Y., \& Murgia, M. (1997). Dividends, Taxes and Signaling Evidence from Germany. The Journal of Finance, 52, 397-408. https://doi.org/10.1111/j.1540-6261.1997.tb03822.x

Asquith, P., \& Mullins, D. (1983). The impact of initiating dividend payment on shareholder's wealth. The Journal of Business, 56, 77-96. https://doi.org/10.1086/296187

Bagwell, L. (1992). Dutch auction repurchase: an analysis of shareholder heterogeneity. The Journal of Finance, 47, 71-105. https://doi.org/10.1111/j.1540-6261.1992.tb03979.x

Bagwell, L., Simon, L., \& Shoven, J. (1989). Cash Distributions to Shareholders. Journal of Economic Perspectives, 47, 129-140. https://doi.org/10.1257/jep.3.3.129

Baker, H., Farrelly, G. E., \& Edelman, R. (1985). A survey of Management View's on Dividend Policy. Financial Management, 14, 78-84. https://doi.org/10.2307/3665062

Baker, M., \& Wurgler, J. (2000). The equity share in new issues and aggregate stock returns. The Journal of Finance, 55, 2219-57. https://doi.org/10.2139/ssrn.172548

Ball, R., \& Brown, P. (1968). An Empirical Evaluation of Accounting Numbers. The Journal of Accounting Research, 6, 159-178. https://doi.org/10.2307/2490232

Ball, R., Brown, Ph., Finn, F. J., \& Officer, R. R. (1979). Dividend and The Value of The firm: Evidence from the Australian Equity Market. Australian Journal of Management, 4, 13-26. 
https://doi.org/10.1177/031289627900400102

Barclay, M. J. (1987). Dividends, Taxes and Common Stock Price: The Ex-Dividend Day Behavior of Common Stock Prices Before the Income Tax. The Journal of Financial Economics, 19, 31-44. https://doi.org/10.1016/0304-405x(87)90027-4

Bar-Yosef, S., \& Huffman, C. (1988). The Information Content of Dividends: A signalling approach. The Journal of Finance and Quantitative Analysis, 21, 47-58. https://doi.org/10.2307/2330990

Bar-Yosef, S., \& Kolodny, R. (1976). Dividend policy and capital market theory. The Review of Economics and Statistics, 58, 181-190. https://doi.org/10.2307/1924024

Beaver, W. (1968). The Information Content of Annual Earnings Announcements. The Journal of Accounting Research, 6, 67-92. https://doi.org/10.2307/2490070

Ben Naceur, S., Goaied, M., \& Belanes, A. (2006). On the Determinants and Dynamics of Dividend Policy. International Review of Finance, 6(1-2), 1-23. https://doi.org/10.2139/ssrn.889330

Benartzi, S., Michaely, R., \& Thaler, R. (1997). Do Changes in Dividends signal the Future or the Past. The Journal of Finance, 52, 1007-1043. https://doi.org/10.2307/2329514

Bernheim, D. (1991). Tax policy and the Dividend Puzzle. Rand Journal of Economics 2, 455-476. https://doi.org/10.3386/w3434

Bernheim, D., \& Wantz, A. (1995). A Taxed-Based Test of Dividend Signaling Hypothesis. The American Economics Review, 85, 532-551. https://doi.org/10.3386/w4244

Best, R. J., \& Best, R. W. (2001). Prior Information and Market Reaction to Dividend Changes. The Review of Quantitative Finance and Accounting, 17, 361-376.

Bhattacharaya, S. (1979), Imperfect Information, Dividend policy, and "the Bird in the Hand Fallacy". Bell Journal of Economics, 10, 259-270. https://doi.org/10.2307/3003330

Black, F. (1976). The Dividend Puzzle. Journal of Portfolio Management, 2, 5-8. https://doi.org/10.3905/jpm.1976.408558

Brav, A., Graham, J., Harvey, C., \& Michaely, R. (2003). Payout Policy in the $21^{\text {st }}$ century. The Journal of Financial Economics, 77, 486-527. https://doi.org/10.2139/ssrn.571046

Brigham, E., \& Gordon, M. (1968). Leverage, Dividends Policy and the Cost of Capital. The Journal of Finance 23, 85-103. https://doi.org/10.1111/j.1540-6261.1968.tb02999.x

Brown, S., \& Warner, J. (1985). Using daily stock returns: The Case of event Studies. The Journal of Financial Economics, 14, 3-31. https://doi.org/10.1016/0304-405x(85)90042-x

Charest, G. (1978). Dividend Information, Stock Return and Market Efficiency. The Journal of Financial Economics, 6, 297-330. https://doi.org/10.1016/0304-405x(78)90033-8

DeAngelo, H., \& DeAngelo, L. (1990). Dividend Policy and Financial Distress: An Empirical Investigation of Troubled NYSE firms. The Journal of Finance, 45, 1415-143. https://doi.org/10.2307/2328743

DeAngelo, H., \& DeAngelo, L. (2006). The irrelevance of the MM Dividend Irrelevance Theorem. The Journal of Financial Economics, 79, 293-315. https://doi.org/10.2139/ssrn.680855

DeAngelo, H., DeAngelo, L., \& Skinner, D. (1996). Reversal of fortune, dividend signaling and the disappearance of sustained earning growth. The Journal of Financial Economics, 40, 341-371. https://doi.org/10.1016/0304-405x(95)00850-e

Denis, J., Denis, K., \& Sarin, A. (1994). The information content of dividend changes: Cash-flow signaling over investment and dividend clienteles. The Journal of Financial and Quantitative Analysis, 29, 567-587. https://doi.org/10.2307/2331110

Eades, K. (1982). Empirical evidence on dividend as a signal of firms value. The Journal of Financial and Quantitative Analysis, 17(4), 471-500. https://doi.org/10.2139/ssrn.2243505

Elfakhani, S. (1995). An empirical examination of the information content of balance sheet and dividend announcements: A signaling Approach. The Journal of Financial and Strategic decision, 8, 65-76.

Fama, E., \& French, K. (1988). Dividend yield and expectated stock returns. The Journal of Financial Economics, 22, 3-25. https://doi.org/10.1016/0304-405x(88)90020-7

Guizani, M., \& Kouki, M. (2011). Ownership-Control Discrepancy and Dividend Policy: Evidence from Tunisia. 
International Business Research, 5(1). https://doi.org/10.5539/ibr.v5n1p127

Harada, K., \& Nguyen, P. (2005). Dividend changes context and signaling efficiency in Japan. Pacific-Basin Finance Journal, 13, 504-522. https://doi.org/10.1016/j.pacfin.2005.01.001

Healy, P., \& Palepu, K. (1988). Earning information conveyed by dividend initiation and omission. The Journal of Financial Economics, 21, 149-176. https://doi.org/10.1016/0304-405x(88)90059-1

Jensen, M., \& Meckling, W. (1976). Theory of the firm: managerial behavior, agency costs and ownership structure. The Journal of Financial Economics, 3, 305-360. https://doi.org/10.2139/ssrn.94043

John, K., \& Kalay, A. (1982). Costly contracting and optimal payout constraints. The Journal of Finance, 37, 457-470. https://doi.org/10.2307/2327348

John, K., \& Williams, J. (1985). Dividend, Dilution and Taxes: A signaling Equilibrium. The Journal of Finance, 40, 1053-1070. https://doi.org/10.2307/2328394

Kalay, A. (1980). Signaling Information Content and the Reluctance to Cut Dividends. The Journal of Financial and Quantitative Analysis, 15, 855-869. https://doi.org/10.2307/2330564

Lintner, J. (1956). Distribution of Incomes of Corporations among Dividend, retained earnings and taxes. The American Economic Review, 46, 429-443

Lintner, J. (1964). Optimal Dividends and Corporate Growth under uncertainty. The Quarterly Journal of Economics, 78, 49-95. https://doi.org/10.2307/1880545

Michaely, R., Thaler, R., \& Womack, K. (1995). Prices reaction to dividend initiation and omission: Overreaction or drift? The Journal of Finance, 50, 573-608. https://doi.org/10.3386/w4778

Miller, M., \& Modigliani, F. (1961). Dividend Policy, Growth and the Valuation of Shares. The Journal of Business, 34, 411-43. https://doi.org/10.1086/294442

Miller, M., \& Rock, K. (1985). Dividend Policy under Asymmetric Information. The Journal of Finance, 40, 1118-1141. https://doi.org/10.2307/2328393

Nissim, D., \& Ziv, A. (2001). Dividend Changes and Future Profitability. The Journal of Finance, 56, 2111-2133. https://doi.org/10.1111/0022-1082.00400

Ofer, A., \& Siegel, D. (1987). Corporate Financial policy Information and Market Expectations: An Empirical investigation of Dividends. The Journal of Finance, 42, 889-911. https://doi.org/10.2307/2328297

Pettit, R. (1972). Dividend Announcements, Security Performance, and Capital Market Efficiency. The Journal of Finance, 27, 993-1007. https://doi.org/10.1111/j.1540-6261.1972.tb03018.x

Pettit, R. (1976). The impact of Dividend announcements: A reconciliation. The Journal of Business, 49, 86-96. https://doi.org/10.1086/295813

Walter, J. (1956). Dividend Policy and Common Stock Prices. The Journal Finance, 11, 29-41. https://doi.org/10.1111/j.1540-6261.1956.tb00684.x

Walter, J. (1963). Dividend Policy: it's Influence on the Value of the Enterprise. The Journal of Finance, 18, 280-291. https://doi.org/10.2307/2977909

Watts, R. (1973). The information Content of Dividend. The Journal of Business, 46, 191-211. https://doi.org/10.1086/295525

Williams, J. (1988). Efficient Signaling with Dividend, Investments and Stock Repurchases. The Journal of Finance, 43, 737-747. https://doi.org/10.1111/j.1540-6261.1988.tb04605.x

\section{Copyrights}

Copyright for this article is retained by the author(s), with first publication rights granted to the journal.

This is an open-access article distributed under the terms and conditions of the Creative Commons Attribution license (http://creativecommons.org/licenses/by/4.0/). 